\title{
HTATIP2 wt Allele
}

National Cancer Institute

\section{Source}

National Cancer Institute. HTATIP2 wt Allele. NCI Thesaurus. Code C49378.

Human HTATIP2 wild-type allele is located in the 11p15.1 and is approximately $20 \mathrm{~kb}$ in length. This allele, which encodes oxidoreductase HTATIP2 protein, may play a role in anti-apoptotic activity and tumor suppression. 